\title{
PAST, PRESENT AND FUTURE OF JOURNAL OF BALTIC SCIENCE EDUCATION
}

\author{
Muhammet Usak \\ Science and Medical Education Research Center, Turkey
}

Science Education is a multidisciplinary field of study with roots about three centuries ago. Researches in this field were published for the first time in a scientific journal with School Science and Mathematics, which started in 1901. The number of scientific journals in Science Education has increased in parallel with the increase in the number of related research. The published literature is sometimes about trending topics. In some other cases, they offer novelty and new paradigms. Last 50 years of Science Education are shaped by various topics. Hence, these different issues are being published in scientific journals. At the end of the 70s, studies on constructivism, meaningful learning, misconception, conceptual learning (Driver, \& Easley, 1978; Driver, 1983; Driver, \& Oldham, 1986; von Glasersfeld, 1984; Ausubel, Novak, \& Hanesian, 1978; Novak, 1979 \& 1990, Novak, \& Gowin, 1984; Novak, \& Musonda, 1991) began to come forward. Conferences are being held especially on misconception. Many articles have been published and continue to be published on the topic. Starting with the second half of 80s, studies on PCK, which were first described by Shulman, began to surface in science education journals in the field of teacher training (Shulman, 1986; Usak, 2009, Usak, Ozden, \& Eilks, 2011; Usak, Ozden, \& Saglam, 2011).

At the beginning of 2000 's, Dr. Vincentas Lamanauskas founded Journal of Baltic Science Education (abbrev. as JBSE). In the early years, the journal published abstracts in Russian, along with English. The year 2008 has been a significant milestone for JBSE in terms of indexing. JBSE started to be indexed by both $\mathrm{SSCl}$ and SCOPUS. Couple of months before this milestone, along with Dr. Pavol Prokop, we published an editorial titled "Science education journals and citation indexes: What should we do?" in the second issue of 2008 (Prokop \& Usak, 2008). Following days, the question "What should we do?" has been answered.

New research topics and approaches emerged at the end of 2000's. This was the era when TPACK was extremely popular (Koehler, Mishra, 2005 \& 2009; Alrwaished et al., 2017; Oskay, 2017) and STEM has just started to come to life with a limited number of scientific works (Eilks, Markic, 2014; Osman, Saat, 2014; Martin et al., 2016; Rakich \& Tran, 2016; Furner, 2017; Thibaut et al., 2018). In this editorial, I decided to make a general evaluation and comparison of the articles published after 2008.

JBSE published 3 articles on TIMMS and PISA, which are international surveys. These works provide evaluations in the sense of global socio-cultural aspects. These studies assess the outcomes of the Czech Republic and Estonia, and present findings and suggestions. While JBSE published few articles on TPACK, it published 11 articles on STEM, 35 articles on Inquiry based learning, 110 articles on attitude, knowledge, understanding and misconception in science education. Especially, works on misconception are published regularly over the last 7 to 17 volumes, and it is evident that this field of study will continue to be popular.

If we look at the annual number of articles published in JBSE, we observe that the journal has published 18 articles in 2008 and 77 articles in 2017. The journal receives excessive submissions each year. The quality and 
ISSN 1648-3898 /Print/

ISSN 2538-7138/Online/

diversity of the scientific works have always been considered as of primary concern and the number of articles published in JBSE has increased sustainably. There exists no increase in the number of articles in the years 2013 to 2017. JBSE is distinguished as the scientific journal that publishes the least number of articles in the years 2008 to 2017 compared to other journals in the area of science education. The editorial team and reviewers of the journal follows an extremely strict peer-review process.

The diversity and the quality of the articles published in JBSE have always attracted attention by other researchers in the field. If we take into account the geographic diversity of the authors, Turkey, Slovenia, Taiwan, Czech Republic and Indonesia ranks as top 5. The journal aims to attract more authors from USA, Germany, UK, Israel and etc - the leading providers of science education literature - in coming years to increase the diversity and target audience of the journal.

The journal has published many articles with 10 or more citations. Me and my colleagues have published 4 such articles in the journal so far (Bahar et al., 2008; Usak et al., 2009; Kubiatko et al., 2010; Prokop, Usak, \& Erdogan, 2011).

The contributions of authors, reviewers and editors play a vital role in the vivid future of JBSE. Together with the increase and diversification of the studies in the field of science and technology, the journal will be an important representative of quality.

In this editorial, I tried to evaluate last 10 years of JBSE. Hope to see you in more 10 years to come...

\section{References}

Alrwaished, N., Alkandari, A., Alhashem, F. (2017). Exploring in- and pre-service science and mathematics teachers' technology, pedagogy, and content knowledge (TPACK): What next? Eurasia Journal of Mathematics, Science and Technology Education, 13 (9), 6113-6131. https://doi.org/10.12973/eurasia.2017.01053a.

Ausubel, D. P., Novak, J. D., \& Hanesian, H. (1978). Educational psychology: A cognitive view (Second Edition). New York: Holt, Rinehart, and Winston.

Bahar, M., Ozel, M., Prokop, P., \& Usak, M. (2008). Science student teachers'ideas of the heart. Journal of Baltic Science Education, 7 (2), 78-85.

Driver, R., \& Easley, J. (1978). Pupils and paradigms: A review of literature related to concept development in adolescent science students. Studies in Science Education, 5, 61-84.

Driver, R. (1983). The pupil as scientist? Buckingham: Open University Press.

Driver, R., \& Oldham, V. (1986). A constructivist approach to curriculum development in science. Studies in Science Education, $13,105-122$

Eilks, I., Markic, S. (2014). Editorial: Traditions and trends in mathematics, science and technology education in Germany. Eurasia Journal of Mathematics, Science and Technology Education, 10 (4), 229-230. https://doi.org/10.12973/eurasia.2014.1093a.

Furner, J. M. (2017). Helping all students become Einstein's using bibliotherapy when teaching mathematics to prepare students for a STEM world. Pedagogical Research, 2 (1), 01. https://doi.org/10.20897/pedre.201701.

Koehler, M. J., \& Mishra, P. (2005). What happens when teachers design educational technology? The development of technological pedagogical content knowledge. Journal of Educational Computing Research, 32 (2), 131-152.

Koehler, M., \& Mishra, P. (2009). What is technological pedagogical content knowledge (TPACK)? Contemporary Issues in Technology and Teacher Education, 9 (1), 60-70.

Kubiatko, M., Usak, M., Yilmaz, K., \& Tasar, M. F. (2010). A cross-national study of Czech and Turkish university students' attitudes towards ICT used in science subjects. Journal of Baltic Science Education, 9 (2), 119-134.

Martin, S. N., Im, S., Song, J. (2016). Editorial: Past, present, and future of science, mathematics, engineering, and technology education research and practice in South Korea. Eurasia Journal of Mathematics, Science and Technology Education, 12 (7), 1707-1710. https://doi.org/10.12973/eurasia.2016.1529a.

Novak, J. D. (1979). Applying psychology and philosophy to the improvement of laboratory teaching. The American Biology Teacher, 41, 466-74.

Novak, J. D. (1990). Concept mapping: A useful tool for science education. Journal of Research in Science Teaching, 27 (10), 937-949.

Novak, J. D., \& Gowin, D. B. (1984). Learning how to learn. New York, NY: Cambridge University Press.

Novak, J. D., \& Musonda, D. (1991). A twelve-year longitudinal study of science concept learning. American Educational Research Journal, $28(1), 117-153$.

Oskay, O. O. (2017). An investigation of teachers'self efficacy beliefs concerning educational technology standards and technological pedagogical content knowledge. Eurasia Journal of Mathematics, Science and Technology Education, 13 (8), 4739-4752. https://doi.org/10.12973/eurasia.2017.00961a.

Osman, K., Saat, R. M. (2014). Editorial. Science, technology, engineering and mathematics (STEM) education in Malaysia. Eurasia Journal of Mathematics, Science and Technology Education, 10 (3), 153-154. https://doi.org/10.12973/eurasia.2014.1077a.

Prokop, P., \& Usak, M. (2008). Science education journals and citation indexes: What should we do? Journal of Baltic Science Education, $7(2), 62-63$

Prokop, P., Usak, M., \& Erdogan, M. (2011). Good predators in bad stories: Crosscultural comparison of children's attitudes towards wolves. Journal of Baltic Science Education, 10 (4), 229-242. 
Rakich, S. S., \& Tran, V. (2016). A balanced approach to building STEM college and career readiness in high school: Combining STEM intervention and enrichment programs. European Journal of STEM Education, 1 (3), 59. https://doi.org/10.20897/ lectito.201659.

Shulman, L. (1987). Knowledge and teaching: Foundations of the new reform. Harvard Educational Review, 57 (1), 1-23.

Shulman, L. S. (1986). Those who understand: Knowledge growth in teaching. Educational Researcher, 15 (2), 4-14.

Thibaut, L., Ceuppens, S., De Loof, H., De Meester, J., Goovaerts, L., Struyf, A.... Depaepe, F. (2018). Integrated STEM education: A systematic review of instructional practices in secondary education. European Journal of STEM Education, 3 (1), 02. https:// doi.org/10.20897/ejsteme/85525.

Usak, M. (2009). Preservice science and technology teachers' pedagogical content knowledge on cell topics. Kuram Ve Uygulamada Egitim Bilimleri, 9 (4), 2033-2046.

Usak, M., Ozden, M., \& Eilks, I. (2011). A case study of beginning science teachers' subject matter (SMK) and pedagogical content knowledge (PCK) of teaching chemical reaction in Turkey. European Journal of Teacher Education, 34 (4), 407-429.

Usak, M., Ozden, M., \& Saglam, Y. (2011). Use of pedagogical content knowledge in teaching chemistry in early science education. Asian Journal of Chemistry, 23 (11), 4761-4767.

Usak, M., Prokop, P., Ozden, M., Ozel, M., Bilen, K., \& Erdogan, M. (2009). Turkish university students' attitudes toward biology: The effects of gender and enrolment in biology classes. Journal of Baltic Science Education, 8 (2), 88-96.

von Glasersfeld, E. (1984). An introduction to radical constructivism. In: P. Watzlawik (Ed.), The invented reality. London: W. W. Naughton \& Co. 